
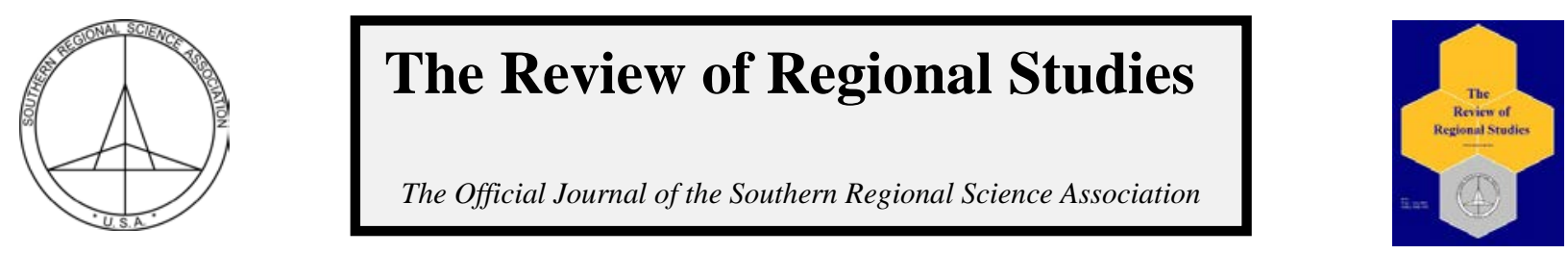

\title{
Untargeted Incentives and Entrepreneurship: An Analysis of Local Fiscal Policies and Small Businesses in Florida
}

\author{
Hai (David) Guo and Shaoming Cheng \\ Department of Public Administration, Steven J. Green School of International and Public Affairs, Florida International \\ University, USA
}

\begin{abstract}
This paper examines the effects of local taxes and local fiscal expenditures on small businesses in Florida. Our analysis sheds light on the linkage between small business development and local fiscal decisions, which seem to have no obvious or direct connection with targeted business assistance and incentives. Spatial panel regression models are calibrated with county-level tax, expenditure, and social and economic factors for the period of 20082013. The estimation results suggest that local tax and expenditure structure and decisions affect the number of small business establishments not only in their "home" counties but also in their neighboring jurisdictions.
\end{abstract}

Keywords: small business, fiscal policy, entrepreneurship

JEL Codes: H71, H72, R12

\section{INTRODUCTION}

The geography of new and small businesses, in light of their abilities to innovate and create new jobs, has been extensively examined in terms of the geographic distribution, the social, economic, and policy determinants within and across jurisdictions, and the impacts on wealth and job creation over time and across geography (Acs and Armington, 2006; Audretsch, Dohse, and Niebuhr, 2010; Cheng and Li, 2012). Consequently, a great number of international, national, and local policies and programs have been established for fostering small businesses (e.g., National Conference of State Legislatures, 2012; OECD, 1998). Previous studies on startup determinants usually focus on various governmental assistance and incentive programs, such as small business loans or empowerment zones.

However, economic incentives targeted at specific businesses have become increasingly, sometimes prohibitively, expensive, yet they demonstrate limited if any positive impacts on economic development (for a review, see Bartik (2002) and Buss (2001)). Most recently, Patrick (2016) focused on the most costly and prominent incentive packages, megadeals that often involve subsidies of $\$ 75$ million or more, and found that successfully recruiting a large, expensive plant may merely induce modest increases in new economic activities and generate no fiscal surplus. Such minimal fiscal/economic impact of targeted economic incentives have been referred to as the "winner's curse" when the winning bid exceeds the intrinsic benefits of attracted megadeal businesses. Similarly, governmental incentives and concessions for luring entrepreneurs and prospective business owners, instead of megadeal corporations, in hopes of

Hai Guo and Shaoming Cheng are Associate Professors of Public Administration at Florida International University, Miami, FL 33199. Corresponding Author:S. Cheng Author E-mail: scheng@fiu.edu.

(C) Southern Regional Science Association 2018.

ISSN 1553-0892, 0048-749X (online)

www.srsa.org/rrs 
fostering entrepreneurship and small business development are equally subject to the "winner's curse” criticism (Shane, 2009). Focusing simply and sometimes exclusively on assistance and incentive programs helps produce the illusion that entrepreneurs and small business owners are predominately interested in and are affected by such programs. They are not. On the contrary, entrepreneurs and small business owners may be first and foremost influenced by local economic fundamentals and by local fiscal policy decisions, which are at odds with the preconceived notion of the essential role of targeted incentives in enhancing entrepreneurship and small business development.

Furthermore, whereas the commonly used incentive policies are repeatedly questioned regarding their effectiveness, these incentive programs may encourage rent-seeking behavior leading to unintended perverse consequences. Baumol (1990) pointed out that entrepreneurial individuals/firms may elect to devote their efforts to productive activities in job and wealth creation, or to unproductive or even destructive activities in securing wealth redistribution through lobbying and corruption. Driven by such rent-seeking motives, entrepreneurs and firms operating in an environment of readily available and pervasive incentives may be induced to lobby and/or bribe for tax breaks and other subsidies that may boost their profits. Firms seek to create a bidding war between two or more state and or local governments to increase the value of the incentives and rents the firm can extract from these government agencies, thus further diminishing the potential benefits of the incentive programs and policies to the state and local economies (Ellis and Rogers, 2000; Patrick, 2014).

The purpose of this paper is to examine the effects of local fiscal policies and decisions, particularly property tax and local option taxes as opposed to business taxes which are not specifically aimed at promoting entrepreneurship and small businesses. This study uses counties in Florida to take advantage of the state-level tax uniformity. Significant tax discrepancies across states make inter-state analyses much more problematic. A spatial panel econometric model is calibrated to highlight potential temporal and spatial spillover effects of such local taxes and expenditures. An important implication of this study to policy makers and practitioners is that there is an alternative entrepreneurship development approach focusing on essential local tax and expenditure structures and decisions as opposed to simply creating new and costly incentives and concessions. These types of incentives and concessions incur unnecessary bidding wars and exert little if any impact on new and small businesses.

\section{LITERATURE REVIEW}

The creation of new, often small businesses is regarded as an individual choice (Knight, 1921) out of the trade-off among unemployment, self-employment, and employment, depending on the costs and returns of the three alternatives. For instance, opening a start-up would be an entrepreneur's rational choice if the perceived profits from owning a new firm exceed his/her actual or perceived wage (Evans and Jovanovic, 1989; Evans and Leighton, 1989). As a result, new firm formation is regarded as a behavioral manifestation of entrepreneurship (Hebert and Link, 1989; Wennekers and Thurik, 1999) or an organizational extension of individual entrepreneurial actions (Gartner, 1989; Lumpkin and Dess, 1996).

Guided by the individual choice approach, entrepreneurs' idiosyncratic individual traits and human capital characteristics that may be conducive to entrepreneurial spirit have been extensively examined in the prior literature. Over the years, the list of individual characteristics has grown and includes alertness, intelligence, aggressiveness, business leadership, high risk 
tolerance, internal locus of control, motivation to succeed, previous experience, and so on (Johnson and Cathcart, 1979; Herbert and Link, 1983; Mokry, 1988; Shaver and Scott, 1991; Wiklund and Shepherd, 2003). Individuals who possess one, a few, or a combination of such traits are regarded to be more likely to start and own new and small businesses. Such studies on personal characteristics often rely on survey methods, which in most cases suffer from low response rates. Further, the statistical relation between firm creation and growth and personal traits and intentions tends to be rather weak. It is likely that the effect of individual intentions is moderated by environmental or contextual factors, for example, access to resources.

In addition to the possession of individual traits, geographic concentration of population with desirable human capital characteristics was another important reason for explaining spatial patterns of new firm formation. Geographic concentration of human capital in terms of either educational attainment (Evans and Leighton, 1990; Bates, 1991; Acs and Armington, 2006) or the percentage of adults with college degrees (Glaeser, Scheinkman, and Shleifer, 1995) is also an important factor influencing the geography of newly created businesses.

Earlier studies on existence of individual traits and geographic distribution of human capital may be able to shed light on individual choices of opening and owning new businesses and on uneven geographic distribution of new and small ventures. However, such line of research has not fully addressed why individuals with entrepreneurial traits and human capital characteristics are geographically concentrated. This paper relies explicitly on the Tiebout competition model (Tiebout, 1956) and focuses primarily on the local tax and expenditure structure on location choices of entrepreneurs and their new and small firms.

The optimal bundle of local taxes and public goods provided by local governments, according to the Tiebout competition model, has played a critical role in deciding where a person lives. Tiebout posits that local jurisdictions, often within a metropolitan area, provide their residents different combinations of public goods and government services, such as parks and recreation, by imposing upon the residents different tax rates as prices for public goods and services. Because residents tend to have varied preferences and valuations of the goods and services and have varied willingness and ability to pay, residents are said to "vote with feet" (Tullock, 1971). In other words, individuals, driven by utility maximization, shop around and move from one jurisdiction to another.

The Tiebout sorting process for residential location choices may be expanded to shed light on the location decisions of new startups. First, new startups' locations are often coupled with business owners' residential location choices in light of the pervasiveness of home-based small businesses in the U.S. With the advent and surge of affordable information technologies and e-commerce logistics, more and more entrepreneurs are launching businesses from their homes. It is estimated in the 2012 Global Entrepreneurship Monitor Report that in the U.S. over two-thirds of all new firms started at home and about 59 percent of established businesses with active employees continue to be operated out of business owners’ homes (Kelley at al., 2012). The coupling of residential and firm location choices, i.e., where to start a business equates where to live, renders entrepreneurs to the Tiebout sorting process in deciding the co-locations of their homes and startups.

The second reason that the Tiebout sorting process for residential location choices is highly relevant for startup locations is because startups are often geographically proximate to entrepreneurs' residence. The decision of where to open and operate a business is likely 
dominated, if not pre-determined, by where to live even if new firms are founded and operated outside of entrepreneurs' residences (Baltzopoulos and Broström, 2011). Entrepreneurs tend to create and run their new firms locally to tap into the local knowledge of relevant business resources (Koster and Venhorst, 2014), to utilize local social ties and networks (Dahl and Sorenson, 2012), and to access localized business financing (Kerr and Nanda, 2009). In addition, even in the absence of the benefits derived from the locational match between residential and firm locations, Stam (2007) suggested entrepreneurs' residential location preferences and behaviors may supersede firm interests when entrepreneurs actively pursue and realize their optimal residential choices even if this may incur additional costs for the firms. Figueiredo, Guimaraes, and Woodward (2002) also showed that entrepreneurs and small business owners are willing to keep their businesses in areas where they reside at the expense of facing and absorbing higher labor costs. The highly aligned residential and firm location decisions make the location choices of small businesses to be highly subject to the Tiebout sorting process.

Last but not least, even if residential and business locations are separated and assumed to be independent, firm locations are influenced by local fiscal and institutional situations which are essential to the Tiebout theory. Besides traditional cost and demand factors (for a review, see Isard (1956)), institutional and other non-economic factors have played increasingly important roles in location decisions. Personal preferences on and hence personal satisfaction from the quality of life, social environment, weather, and landscape are significant determinants of where to open and operate a firm (Hoover, 1948; Greenhut, 1967; Richardson, 1969). Recognizing the critical role of personal factors, Tiebout (1957) stressed that small firms compared to their larger counterparts are more likely to be influenced by these non-pecuniary determinants. Recent literature on the creative class, talent attraction, and retention further emphasizes urban, cultural, and residential amenities and their role in attracting and cultivating a local, productive workforce (Florida, 2002; 2004). The amenity-oriented firm location approach maintains that amenities attract not only residents but also firms, and suggests business entrepreneurs and owners in their location decision process will evaluate certain amenities with respect to the likely residential locations of their employees (Gottlieb, 1995; Koster and Venhorst, 2014). In this sense, selecting business locations can be united with residential locations through the availability and provision of residential amenities which are at the core of the Tiebout sorting theory.

This paper builds upon the Tiebout sorting process for residential location choices and further expands it to test how entrepreneurs or prospective entrepreneurs sort alternative locations for opening and running their new businesses when facing various bundles of local public goods and services and taxes. The Tiebout sorting of business entrepreneurs and owners are not entirely different from that of general residents. Imposed taxes are a cost for utility maximization of residents and for profit maximization of new and small businesses. Prospective and current entrepreneurs will simply open start-ups in a community that offers a level of public goods and services that suits them. The business location decisions, however, can be separated from residential location choices because the optimal bundles of goods and services and associated taxes may not be the same for business profit maximization and household utility maximization.

\section{RESEARCH QUESTION AND HYPOTHESES}

This paper examines how local taxes and expenditures affect small business establishments, under the assumption that business owners will also be involved in a Tiebout 
sorting process to find the location that provides the public goods and services best suited for their needs. Four major local taxes are empirically tested in the paper: the property tax, the local option sales tax, the local option fuel tax, and the local communications service tax. The Florida State Constitution authorizes local governments to collect property tax for their operation, which accounted for 73 percent of total county tax revenues in 2013. The local option sales tax is part of the eight types ${ }^{1}$ of surtax. Both the potential maximum surtax rates and actual rates vary among county governments due to different combinations of levies in each county. In addition, authorized by the state legislature, county governments in Florida have three types of fuel tax levies that add up to 12 cents in total, but the actual rates vary as some counties choose whether or not to levy the maximum rate. County governments in Florida can choose to levy a local communication service tax by ordinance and set the rate at their discretion (EDR, 2014). The total revenue yielded by these taxes takes up to 97 percent of the total tax revenue of all counties in Florida in 2013. ${ }^{2}$ The four types of taxes selected are all tightly related to the tax authority of local jurisdictions but are not traditionally used for small business attraction and development nor have they been examined for their effects on the location of small business establishments. A case study of Florida will be presented in the paper in part to maintain tax uniformity and comparability across jurisdictions.

Three hypotheses will be tested in this paper, and they are:

Hypothesis 1: Higher millage rates of local property tax hinder small business creation, when local expenditure is controlled.

Hypothesis 2: Higher local option sales tax rates, local option fuel tax rate, and communication services tax rate hinder the creation of small business establishments, when local expenditure is controlled.

Hypothesis 3: Higher local expenditure on physical environment, economic environment, transportation, public safety, human services, and culture/recreation encourage the creation of small business establishments, when local tax rates are controlled.

\section{DATA AND VARIABLES}

The areal units for the examination are Florida's 66 counties. ${ }^{3}$ The county-level analysis is superior to most of the prior studies because previous research has been at a highly aggregated geographic level, for example, individual states (Carree, 2002; Acs and Armington, 2006) or labor market areas (LMAs) (Reynolds, Miller, and Maki, 1995; Armington and Acs, 2002; Lee, Florida, and Acs, 2004). The earlier approaches may not only mask intra-unit variations but also are susceptible to modifiable areal unit problem (MAUP) bias when underlying economic relations do not match the boundaries of administratively determined states or other aggregated

\footnotetext{
${ }^{1}$ The eight surtaxes include the charter, county, and regional transportation system surtax, the local government infrastructure surtax, the small county surtax, the indigent care/trauma center surtaxes, the county public hospital surtax, the voter-approved indigent care surtax, the emergency fire rescue services and facilities surtax, and the school capital outlay surtax.

2 Authors' calculation is based on the data provided by the Florida Department of Financial Services Bureau of Local Government.

${ }^{3}$ There are 67 counties in Florida. Monroe County is excluded from the analysis, because it is an outlier in the number of small businesses in part due to its remoteness to the rest of the state and due to its tourism-oriented economy.
}

(c) Southern Regional Science Association 2018. 
geographic units. For each of the counties, small business numbers are standardized by the size of the county's total labor force, consistent with the labor force approach established in Audretsch and Fritsch (1994). Information on small businesses in Florida's counties is obtained from the County Business Patterns of the U.S Census Bureau. The publicly available dataset provides information on the stock of small businesses categorized by their employee sizes, and the dependent variable in spatial regressions is the stock of small businesses with 1-4 employees standardized by 1,000 labor force in 2008-2013. It is important to note that the publicly available information based on the stocks of businesses may not provide accurate numbers of newly

Table 1: Variable Descriptions and Sources

\begin{tabular}{|c|c|c|c|}
\hline Variable & Description & Expected sign & Source \\
\hline \multicolumn{4}{|l|}{ Dependent variable } \\
\hline Small businesses & $\begin{array}{l}\text { Numbers of small ventures (1-4 } \\
\text { employees) per } 1000 \text { labor force }\end{array}$ & & $\begin{array}{l}\text { County } \\
\text { Business Patten }\end{array}$ \\
\hline \multicolumn{4}{|l|}{ Independent variables } \\
\hline \multicolumn{4}{|l|}{ Tax Rates } \\
\hline Millage rate & Property tax millage rate & - & \multirow{11}{*}{$\begin{array}{l}\text { Florida } \\
\text { Department of } \\
\text { Financial } \\
\text { Services } \\
\text { Bureau of } \\
\text { Local } \\
\text { Government }\end{array}$} \\
\hline Fuel tax rate & Local option fuel tax rate & - & \\
\hline Communication tax rate & Local communication services tax & - & \\
\hline Sales surtax rate & Local option sales tax rate & - & \\
\hline \multicolumn{3}{|l|}{ Expenditures } & \\
\hline Public safety & Public safety expenditure per capita & + & \\
\hline Physical environment & $\begin{array}{l}\text { Physical environment expenditure per } \\
\text { capita }\end{array}$ & + & \\
\hline Economic environment & $\begin{array}{c}\text { Economic environment expenditure per } \\
\text { capita }\end{array}$ & + & \\
\hline Transportation & Transportation expenditure per capita & + & \\
\hline Human services & Human services expenditure per capita & + & \\
\hline Culture/recreation & Culture/recreation expenditure per capita & + & \\
\hline \multicolumn{4}{|l|}{ Traditional factors } \\
\hline Avg. establishment size & $\begin{array}{c}\text { Average employment per establishment } \\
\text { for all industries }\end{array}$ & - & \multirow{8}{*}{$\begin{array}{l}\text { U.S. Census } \\
\text { Bureau }\end{array}$} \\
\hline Unemployment rate & Unemployment rate & + & \\
\hline College \% & $\begin{array}{l}\text { Proportion of the population having at } \\
\text { college degree }\end{array}$ & + & \\
\hline Population & Annual Population & + & \\
\hline Population growth & Annual population growth rate & + & \\
\hline Personal income & Annual personal income per capita & + & \\
\hline Personal income growth & Annual per capita income growth rate & + & \\
\hline Median housing value & Median house value & - & \\
\hline Share of proprietors & Share of proprietors in labor force & + & U.S. BEA \\
\hline
\end{tabular}


created firms over the years, because the net changes in the stock of firms over the years is influenced jointly by firm births and deaths. In addition, small businesses are not synonymous with entrepreneurship because not all small, new, and young businesses are driven by the entrepreneurial spirit, but generally small businesses have been widely used as an indicator for entrepreneurship (Audretsch and Fritsch, 1994; Armington and Acs, 2002; Acs and Armington, 2006; Delgado, Porter, and Stern, 2010).

Key individual variables consist of nominal rates of the four types of local taxes, namely, property tax, local option sales tax, local option fuel tax, and local communications services tax. In addition, individual counties' per capita expenditures in public safety, transportation, physical environment, economic environment, human services, and culture/recreations are also collected and used in the regression analyses to control for different usages of tax revenues across local jurisdictions. Notably, local expenditures on the economic environment may serve as a proxy of local economic incentives targeted at business attraction and formation in general. Both the local tax and expenditure information is collected from the Florida's Department of Financial Services Bureau of Local Government. Furthermore, factors derived from earlier literature are also included in the regression models (Armington and Acs, 2002; Acs and Armington, 2006). These other controls are the average employment per establishment for all industries, the annual per capita income, the annual per capita income growth rate, the share of proprietors in the labor force, the annual population, the annual population growth rate, and educational attainment. Furthermore, median house values are included to control the effects of housing prices on small business establishments. Tables 1 and 2 present detailed descriptions, data sources, and summary statistics for all the independent variables. Table 3 presents a correlation matrix for the independent variables used and no serious multicollinearity concern is apparent.

\section{SPATIAL PANEL MODELS}

The longitudinal data of 66 counties from 2008 to 2013 provide rich information to examine how local government taxes and expenditures affect small business establishments. Moreover, the analysis also considers the spatial relationship among counties. Not only do the business establishments exhibit spatial dependence, local government finance data often has spatial autocorrelation that is often neglected. Brueckner (2003) highlights the necessity of spatial economic methods in the study of local governments’ public finance.

Traditionally, spatial econometric models take into account the spatial dependence occurring either in the dependent variable or in the error term, which respectively leads to a spatial autoregressive (SAR) model or a spatial error model (SEM). The SAR model is used under circumstances that spatial autocorrelation exists in the dependent variable while the SEM model considers that spatial dependence exists in the error term. Spatial models have been further expanded into various forms, and the following equations represent different spatial model specifications when certain parameters are set to zero (for a review see Elhorst (2010) and LeSage and Pace (2009)).

$$
\begin{aligned}
\text { SAR }: \mathbf{y} & =(\mathbf{I}-\rho \mathbf{W})^{-1}(\alpha \boldsymbol{\tau}+\mathbf{X} \boldsymbol{\beta})+(\mathbf{I}-\rho \mathbf{W})^{-1} \boldsymbol{\varepsilon} \\
\text { SDM }: \mathbf{y} & =(\mathbf{I}-\rho \mathbf{W})^{-1}(\alpha \boldsymbol{\tau}+\mathbf{X} \boldsymbol{\beta}+\mathbf{W X} \boldsymbol{\theta})+(\mathbf{I}-\rho \mathbf{W})^{-1} \boldsymbol{\varepsilon} \\
\text { SLX : } \mathbf{y} & =\alpha \boldsymbol{\tau}+\mathbf{X} \boldsymbol{\beta}+\mathbf{W X \boldsymbol { \theta }}+\boldsymbol{\varepsilon} \\
\text { SDEM }: \mathbf{y} & =\alpha \boldsymbol{\tau}+\mathbf{X} \boldsymbol{\beta}+\mathbf{W X} \boldsymbol{\theta}+\boldsymbol{\mu}, \quad \boldsymbol{\mu}=\lambda \mathbf{W} \boldsymbol{\mu}+\boldsymbol{\varepsilon}
\end{aligned}
$$


Table 2: Descriptive Statistics ( $N=396)$

\begin{tabular}{lcccc}
\hline & Mean & S.D. & Min & Max \\
\hline Dependent Variable & & & & \\
Small businesses & 12.25 & 4.30 & 4.01 & 22.45 \\
\hline Tax Rates & & & & \\
Millage rate & 7.58 & 1.84 & 3.31 & 13.00 \\
Fuel tax rate & 50.03 & 2.59 & 44.90 & 54.60 \\
Communication services tax rate & 2.63 & 1.59 & 0.29 & 7.38 \\
Sales surtax rate & 0.73 & 0.46 & 0.00 & 1.50 \\
\hline Expenditures (Log transformed) & & & & \\
Public safety exp. & 6.04 & 0.30 & 5.37 & 7.17 \\
Physical environment exp. & 4.84 & 0.92 & 2.10 & 7.77 \\
Transportation exp. & 5.29 & 0.53 & 3.86 & 7.46 \\
Economic Environment exp. & 3.62 & 0.83 & 0.24 & 5.83 \\
Human services exp. & 3.82 & 0.79 & 1.93 & 6.82 \\
Culture/recreation exp. & 3.94 & 0.68 & 2.18 & 5.92 \\
\hline Traditional Factors & & & & \\
Average establishment size & 10.82 & 2.57 & 6.13 & 19.74 \\
Unemployment rate & 9.02 & 2.17 & 4.40 & 14.70 \\
College \% & 19.25 & 8.72 & 5.8 & 44.2 \\
Population (log transformed) & 11.56 & 1.49 & 9.01 & 14.77 \\
Population growth rate & 0.73 & 1.28 & -4.70 & 5.50 \\
Person Income (log transformed) & 10.37 & 0.29 & 9.65 & 11.19 \\
Personal income growth rate (log transformed) & 1.14 & 3.76 & -15.20 & 12.80 \\
Median housing value (log transformed) & 11.89 & 0.35 & 11.16 & 12.83 \\
Proprietors \% & 26.41 & 7.95 & 10.95 & 54.48 \\
\hline \hline
\end{tabular}

The selection of specific spatial model depends on the theoretical and intuitive understanding of the global vs. local spatial spillovers of entrepreneurs' location decisions in response to provision and prices of public goods and services. Mathematically, global spillovers arise from spatial lags that lead to reduced form expressions involving: $(\mathbf{I}-\rho \mathbf{W})^{-1}=\mathbf{I}+\rho \mathbf{W}+\rho^{2} \mathbf{W}^{2}+\ldots$ Both the spatial autoregressive regression (SAR) and the spatial Durbin model (SDM) capture the global spatial spillovers, while the spatially lagged $\mathrm{X}$ regression (SLX) and spatial Durbin error model (SDEM) reflect the local spillover effects. ${ }^{4}$ Among the four most commonly used spatial models, the SDM and SDEM are more general models compared to the SAR and SLX respectively, because SDM subsumes SAR if $\theta=0$ while SDEM subsumes SLX if $\lambda=0$. The general models are more efficient in parameter estimation if the spatial correlation is present, i.e., the corresponding spatial correlation coefficients are nonzero (LeSage and Pace, 2009).

\footnotetext{
${ }^{4}$ The terminology of SAR, SDM, SLX and SDEM is from LeSage and Pace (2009).

(c) Southern Regional Science Association 2018.
} 
Table 3: Correlation Table of Independent Variables

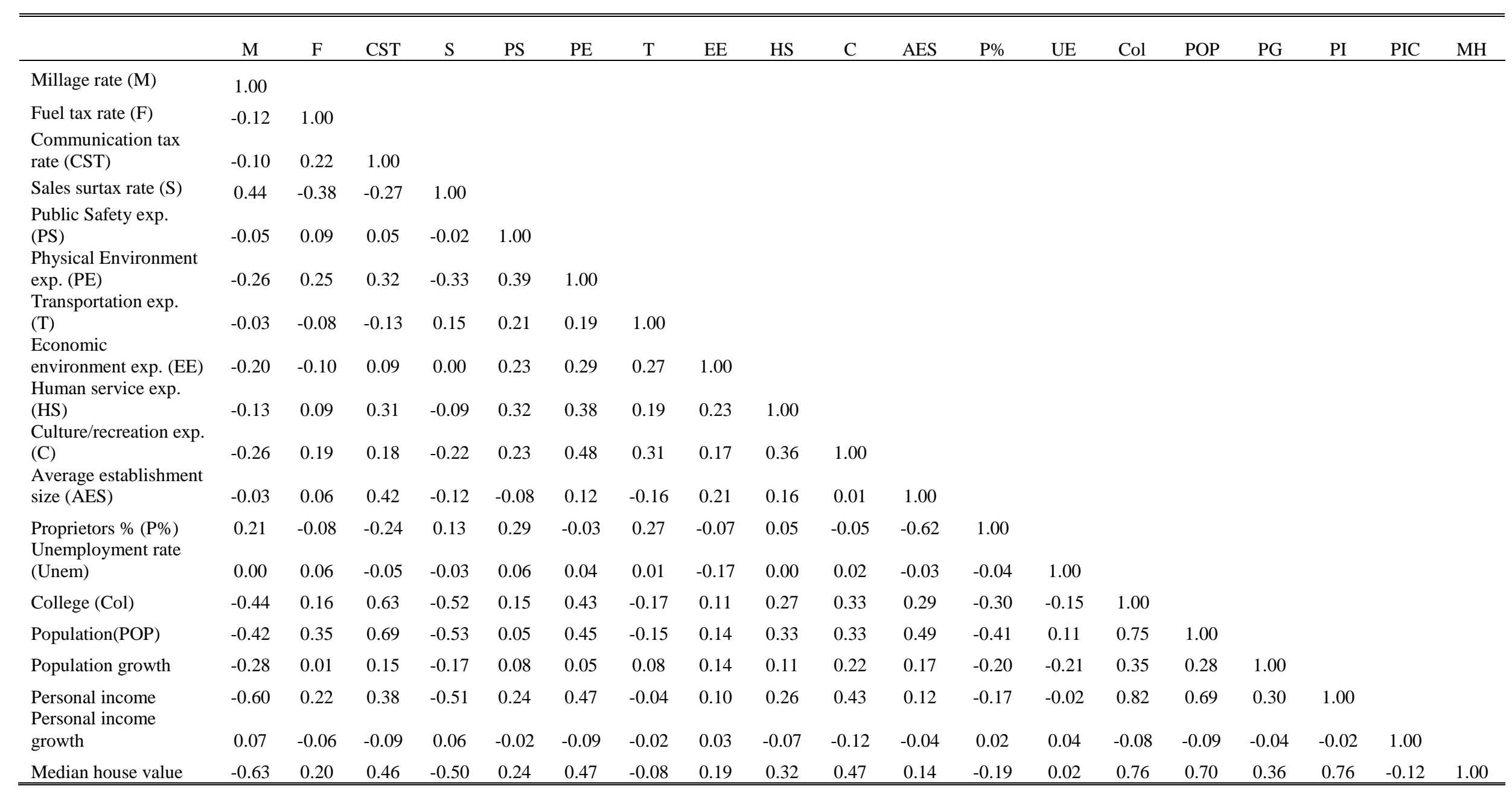


Intuitively and theoretically speculated by Tiebout sorting, the availability of public goods and services is likely to exert a local spillover impact on entrepreneurs and their decisions of which county to live and open their startups. They are likely to locate and relocate to an adjacent municipality/county other than to those of a great distance. In this sense, local spatial spillover models, such as the SLX or the SDEM, are, theoretically, suited for our analysis.

Furthermore, to empirically test and determine model specification, the Bayesian model comparison approach (LeSage, 2014; 2015) will be applied by calculating posterior model probabilities associated with alternative models, specifically the SLX, SDM, and SDEM. The model specification, which has the highest posterior model probability, will be selected because it best fits the data and any prior distributions assigned to the parameters. The alternative model selection method to the Bayesian procedure is log-likelihood function values (Anselin et al., 1996; Elhorst, 2010; 2014). LeSage and Pace (2009) summarized that the two methods will generate consistent results, but the Bayesian procedure is advantageous in its application in nonnested model comparisons.

In general, the aforementioned spatial models can be expanded from cross-sectional into panel models as follows:

$$
\begin{gathered}
\boldsymbol{y}_{i t}=\delta \sum_{j=1}^{\mathrm{N}} \boldsymbol{w}_{i j} \boldsymbol{y}_{j t}+\boldsymbol{x}_{i t} \beta+\sum_{j=1}^{N} \boldsymbol{w}_{i j} \boldsymbol{x}_{i j t} \gamma+\mu_{i}+\lambda_{t}+\boldsymbol{u}_{i t} \\
\boldsymbol{u}_{i t}=\rho \sum_{j=1}^{N} \boldsymbol{w}_{i j} u_{i t}+\boldsymbol{\varepsilon}_{i t}
\end{gathered}
$$

where $i$ and $j$ are the index for cross-sectional units and $t$ is the time unit. $y_{\text {it }}$ is the dependent variable, i.e., the number of small business establishments per 1,000 labor force in county $i$ in year $t$. $x_{i t}$ contains a matrix of explanatory variables listed in Table 1 . The error terms $\mu_{i}$ and $\lambda_{t}$ represent cross-sectional invariant and time invariant unobserved effects, and $W$ represents the spatial weighting matrix. As shown in Equation 2, the position of the weighting matrix indicates different spatial econometric models. If the model only contains a spatially lagged dependent variable, i.e., $\gamma$ and $\rho$ are set to zero, Equation 2 represents the SAR model. With both spatially lagged dependent and explanatory variables ( $\rho$ is set to zero), the equation is the SDM model. If the model only has spatially lagged independent variables, i.e., $\delta$ and $\rho$ are set to zero, Equation 2 represents the SLX model. Last but not least, SDEM model is derived if $\delta$ is set to zero while $\gamma$ and $\rho$ are nonzero. Estimation of all of the spatial panel models can be achieved by the Bayesian Markov Chain Monte Carlo (MCMC) method (LeSage, 2015). ${ }^{5}$

\section{EMPIRICAL FINDINGS}

The Bayesian model selection procedure illustrated in LeSage (2014) suggests that the SDEM model (34.8 percent) has a slightly higher posterior model probability compared to the SLX (30.8 percent) and the SDM (34.4 percent) specifications. But because of the very close posterior model probabilities, all three model specifications are calibrated. The results of the three model specifications are highly consistent in terms of the estimated coefficients' signs,

\footnotetext{
${ }^{5}$ The Matlab routine posted at Professor James LeSage's website (www.spatial-econometrics.com) will be used.
} 
magnitudes, and statistical significance. Due to page limits, only the SDEM model results are reported. The SLX and SDM results are available upon request.

Table 4 presents the results of the non-spatial fixed effect panel model that does not consider spatial autocorrelation and the SDEM panel specification. In the non-spatial fixed effect panel model, the local option fuel tax rate exhibits a negative and statistically significant effect on the small business establishments. The fuel tax is not a common local option tax. Most state governments do not allow local governments to levy fuel taxes. County governments in Florida can choose to impose as high as 12 cents a gallon tax on gasoline. Combining with the federal and state fuel tax rate, the overall fuel tax rate can reach 54.6 cents a gallon, which is clearly a tax burden that may hinder the development of small businesses. The county government's per capita expenditures on culture and recreation show a positive effect on the numbers of small business establishments at the conventional 5 percent significance level. It is aligned with our argument that residential location decision is highly relevant for small business location decision. Higher expenditures on culture and recreation such as libraries, parks, and culture services are likely to attract not only residents but also entrepreneurs to establish small businesses. The local government's per capita expenditures on economic development shows a statistically significant and negative effect on the small business establishments at a 10 percent significance level. This suggests that if a county government spends more per capita on programs such as employment opportunity and development, industry development, veteran's services, and housing and urban development, it will create more employment opportunities. At the same time, increased job opportunities induced by county governments' programs and investment may likely reduce the necessity or demands for new startups.

Among the traditional factors, education, population, and median house value all exhibit statistically significant effects. As expected, a county with a higher proportion of college graduates has more small business establishments. A larger county with higher median housing values will have fewer small business establishments. It appears that the non-spatial fixed effect model explains 45 percent of the variations of the dependent variable.

Table 4 also presents the estimation results of SDEM panel model. The SDEM model assumes that the spatial cluster and spillovers come from two sources: the observable explanatory variables and the unobserved error terms. The spatial lagged explanatory variables are represented by the multiplication of a contiguity-weighing matrix $(W X)$ for the counties in Florida. With no spatially lagged dependent variables in the model, it simplifies the interpretation of the direct and indirect effect of the model estimation. The coefficients of the explanatory variables are the marginal direct effect and the coefficients of the multiplication of the weighting matrix and the explanatory variables $(W X)$ are the marginal indirect effects, i.e., spatial spillover effects on neighboring counties (LeSage and Pace, 2009).

The R-squared value of the calibrated SDEM panel model is 0.99 because the crosssectional fixed effects account for much of the variation. Elhorst (2010) suggested using the difference between the R-squared and the squared correlation coefficient of actual and fitted values (corr2) to measure the proportion of variations that are explained by fixed effects. In this case, the corr2 value equals to 0.45 , which indicates that the fixed effects explain 0.54 or 54 percent of all the variation of the dependent variable. The higher proportion of explained variation plus the statistically significant SDEM spatial coefficient $(\lambda)$ suggests that the SDEM panel model is superior to the non-spatial fixed effect panel model. Therefore, interpretation of the model estimates will focus on the SDEM panel results. 
Table 4: Non-Spatial and SDEM Panel Model Results

\begin{tabular}{|c|c|c|c|c|c|c|}
\hline \multicolumn{7}{|c|}{ "Dependent Variable: Number of Small Businesses Normalized by 1,000 Labor Force } \\
\hline & \multicolumn{3}{|c|}{ Non-Spatial Fixed Effect } & \multicolumn{3}{|c|}{ Spatial Durbin Error Model } \\
\hline & Coefficients & S.E. & P-value & Coefficients & S.E. & P-value \\
\hline Millage rate & -0.060 & $(0.055)$ & 0.274 & -0.073 & $(0.056)$ & 0.194 \\
\hline Fuel tax rate & $-0.055^{* *}$ & $(0.028)$ & 0.046 & $-0.049 *$ & $(0.028)$ & 0.075 \\
\hline Communication service tax rate & -0.033 & $(0.053)$ & 0.535 & -0.016 & $(0.053)$ & 0.765 \\
\hline Sales surtax rate & 0.109 & $(0.140)$ & 0.437 & 0.213 & $(0.139)$ & 0.126 \\
\hline Public safety exp. & 0.056 & $(0.181)$ & 0.759 & 0.178 & $(0.184)$ & 0.333 \\
\hline Physical environment exp. & 0.018 & $(0.082)$ & 0.823 & -0.020 & $(0.083)$ & 0.808 \\
\hline Transportation exp. & 0.020 & $(0.069)$ & 0.774 & -0.016 & $(0.073)$ & 0.823 \\
\hline Economic environment exp. & $-0.074 *$ & $(0.040)$ & 0.065 & -0.041 & $(0.041)$ & 0.317 \\
\hline Human services exp. & 0.020 & $(0.074)$ & 0.789 & 0.073 & $(0.072)$ & 0.314 \\
\hline Culture/recreation exp. & $0.181 * *$ & $(0.074)$ & 0.014 & 0.173 & $(0.073)$ & 0.017 \\
\hline Average establishment size & -0.084 & $(0.038)$ & 0.027 & $-0.079 *$ & $(0.041)$ & 0.052 \\
\hline Proprietors \% & 0.019 & $(0.022)$ & 0.380 & -0.005 & $(0.023)$ & 0.829 \\
\hline Unemployment rate & -0.010 & $(0.038)$ & 0.794 & -0.001 & $(0.025)$ & 0.970 \\
\hline College \% & $12.529 * * *$ & $(2.501)$ & 0.000 & $10.399 * * *$ & $(2.500)$ & 0.000 \\
\hline Population & $-7.154 * * *$ & $(0.975)$ & 0.000 & $-7.180 * * *$ & $(0.972)$ & 0.000 \\
\hline Population growth rate & $0.038 *$ & $(0.023)$ & 0.099 & 0.037 & $(0.023)$ & 0.110 \\
\hline Personal Income & 1.128 & $(0.806)$ & 0.164 & 0.340 & $(0.791)$ & 0.668 \\
\hline Personal income growth rate & 0.011 & $(0.009)$ & 0.214 & 0.011 & $(0.008)$ & 0.190 \\
\hline Median housing value & $-1.911^{* * *}$ & $(0.424)$ & 0.000 & $-1.519 * * *$ & $(0.490)$ & 0.002 \\
\hline $\mathrm{W}^{*}$ Millage rate & & & & -0.123 & $(0.123)$ & 0.316 \\
\hline $\mathrm{W}^{*}$ Fuel tax rate & & & & 0.009 & $(0.056)$ & 0.872 \\
\hline $\mathrm{W}^{*}$ Communication service tax rate & & & & 0.067 & $(0.112)$ & 0.548 \\
\hline $\mathrm{W}^{*}$ Sales surtax rate & & & & $0.771^{* *}$ & $(0.364)$ & 0.034 \\
\hline $\mathrm{W}^{*}$ Public safety exp. & & & & -0.240 & $(0.381)$ & 0.530 \\
\hline $\mathrm{W}^{*}$ Physical environment exp. & & & & 0.169 & $(0.188)$ & 0.369 \\
\hline $\mathrm{W}^{*}$ Transportation exp. & & & & -0.135 & $(0.178)$ & 0.445 \\
\hline $\mathrm{W}^{*}$ Economic environment exp. & & & & $0.320 * * *$ & $(0.092)$ & 0.001 \\
\hline $\mathrm{W}^{*}$ Human services exp. & & & & 0.224 & $(0.143)$ & 0.116 \\
\hline W*Culture/recreation exp. & & & & -0.010 & $(0.167)$ & 0.955 \\
\hline $\mathrm{W}^{*}$ Average establishment size & & & & $-0.207 * *$ & $(0.098)$ & 0.035 \\
\hline $\mathrm{W}^{*}$ Proprietors \% & & & & $-0.095 * *$ & (0.039) & 0.015 \\
\hline $\mathrm{W} *$ Unemployment rate & & & & -0.029 & $(0.049)$ & 0.557 \\
\hline $\mathrm{W}^{*}$ College $\%$ & & & & -10.083 & (6.186) & 0.103 \\
\hline $\mathrm{W}^{*}$ Population & & & & -1.602 & $(2.225)$ & 0.473 \\
\hline $\mathrm{W}^{*}$ Population growth rate & & & & 0.076 & $(0.051)$ & 0.140 \\
\hline $\mathrm{W}^{*}$ Personal income & & & & $-2.417^{*}$ & $(1.272)$ & 0.057 \\
\hline $\mathrm{W}^{*}$ Personal income growth rate & & & & 0.000 & $(0.010)$ & 0.986 \\
\hline $\mathrm{W}^{*}$ Median housing value & & & & -0.559 & $(0.745)$ & 0.454 \\
\hline \multicolumn{7}{|l|}{ Summary statistics } \\
\hline Spatial autoregressive $(\lambda)$ & & \multirow[t]{2}{*}{$-0.193 * *$} & $(0.087)$ & \multirow[t]{2}{*}{0.026} \\
\hline No. of observations & & & & & 396 & \\
\hline $\mathrm{R}^{2}$ & \multirow{3}{*}{\multicolumn{3}{|c|}{0.452 (within) }} & \multicolumn{3}{|c|}{0.99} \\
\hline $\operatorname{corr}^{2}$ (actual and fitted values) & & & & \multicolumn{3}{|c|}{0.45} \\
\hline Log likelihood & & & & \multicolumn{3}{|c|}{-93.93} \\
\hline
\end{tabular}

Southern Regional Science Association 2018. 
After considering the spatial spillover effect, the estimation of the SDEM panel model shows a noticeable difference compared to the non-spatial fixed effect panel model. The SDEM indicates that county governments' tax and expenditure policies play an important role in the development of small business establishments both for the home counties and the neighboring counties. The direct effect of the local option fuel tax rate remains negative and statistically significant at the 10 percent level, whereas the indirect effect is positive but not statistically significant.

The local option sales surtax rate does not exhibit a statistically significant direct effect on small business establishments, but it has an indirect, spillover effect, which is positive and statistically significant at the 5 percent level. This suggests that if the local option sales tax rises in a county, the number of small business establishments will increase in its neighboring counties as if they were "pushed" into the nearby counties because of the "home" county's higher sales tax rate. This implies that small business owners take the sales tax burden into consideration and are more likely to choose a jurisdiction with a relatively low(er) sales tax rate for their new business establishments. What matters here is not just the absolute sales tax rate in a jurisdiction but how it is compared to its neighboring counties.

The direct effect of the economic environment expenditures remains negative, but is no longer statistically significant, whereas the indirect, spillover effect is positive and statistically significant. If a county government spends more per capita to improve its economic environment, it may not create more small business opportunities within the county but may promote small business development in its neighboring counties. The expenditures on culture/recreation, however, does not exert a statistically significant direct effect on the small business establishments or a statistically significant indirect effect. This may suggest the statistically significant relationship between per capita culture/recreation expenditure and small business establishments in the non-spatial panel model is spurious.

The traditional factors still have the expected signs after controlling for the spatial autocorrelation. Average establishment size exhibits a negative direct effect and indirect effect at a 5 percent level. With a higher proportion of college graduates, a county will have more small businesses within its jurisdiction but fewer small businesses in its neighboring counties. Larger counties with a larger population and higher median housing value tend to be associated with fewer small business establishments.

\section{CONCLUSIONS}

Entrepreneurship and small business establishments have played an essential role in economic development. Cultivating new businesses and high growth ventures have been an important task and goal for policy makers at various levels. However, the "zero sum games" criticism against traditional economic development strategies and targeted incentives has not only given rise to the home grown entrepreneurship-led economic development paradigm but also has reminded us that the "zero sum games" criticism may be applied to excessive governmental incentives intended for small businesses. As governmental incentives offered by different jurisdictions are canceled out, the economic and policy fundamentals of a jurisdiction really matter to the prospective entrepreneurs and business owners.

This research directly examines how small businesses respond to local fiscal policies, both taxes and expenditures, which generally are not targeted for entrepreneurship and small 
business development. We expand the traditional Tiebout model, which focuses primarily on residential location decisions, and apply it to explain how entrepreneurs respond to taxes imposed and public goods provided when deciding where to locate their business. It is hypothesized that a local jurisdiction's fundamental fiscal environment created by the different tax bundles and expenditures affect the small business owners' location decisions. A pilot study on Floridian counties and very small businesses (1-4 employees) is conducted and a proper spatial panel econometric model is calibrated in light of great spatial correlation.

In accordance with LeSage's (2014, 2015) procedure of selecting spatial panel models, the SDEM panel model is supported. The SDEM panel model results show that the local option fuel tax has a negative effect on small business establishments in "home" counties, while both the local option sales surtax tax and per capita expenditures on the economic environment have positive spillover effects on small business establishments in "neighboring” counties. These findings suggest that local fiscal decisions, which are untargeted for entrepreneurship and small business creation or attraction, to some extent and in some areas, influence small business development not only in "home" counties but also in adjacent counties.

This study uses data from only one state, which may limit its generalizability. However, one state data allows us to control state-specific heterogeneity and to take advantage of tax uniformity. This study has six years of data that includes the recent Great Recession. A longer panel may be more informative in the way that local governments' long-term fiscal environment can be captured.

\section{REFERENCES}

Acs, Zoltan J. and Catherine Armington. (2006) Entrepreneurship, Geography, and American Economic Growth. Cambridge University Press: Cambridge, Massachusetts.

Anselin, Luc, Anil K. Bera, Raymond Florax, and Mann J. Yoon. (1996) “Simple Diagnostic Tests for Spatial Dependence,” Regional Science and Urban Economics, 26, 77-104.

Armington, Catherine, and Zoltan J. Acs. (2002) "The Determinants of Regional Variation in New Firm Formation,” Regional Studies, 36, 33-45.

Audretsch, David, Dirk Dohse, and Annekatrin Niebuhr. (2010) "Cultural Diversity and Entrepreneurship: A Regional Analysis for Germany,” Annals of Regional Science, 45, 55-85.

Audretsch, David B. and Michael Fritsch. (1994) “On The Measurement of Entry Rates,” Empirica, 21, 105-113.

Baltzopoulos, Apostolos and Anders Broström. (2011) “Attractors of Entrepreneurial Activity: Universities, Regions and Alumni Entrepreneurs,” Regional Studies, 47, 934-949.

Bartik, Timothy J. (2002) "Evaluating the Impacts of Local Economic Development Policies on Local Economic Outcomes: What Has Been Done and What Is Doable?” Upjohn Institute Staff Working Paper 03-89. Kalamazoo: Michigan.

Bates, Timothy. (1991) "Commercial Bank Financing of White and Black Owned Small Business Start-Ups,” Quarterly Review of Economics and Business, 13, 64-80.

Baumol, William J. (1990) “Entrepreneurship: Productive, Unproductive and Destructive,” Journal of Political Economy, 98, 893-921.

(c) Southern Regional Science Association 2018. 
Brueckner, Jan K. (2003) "Strategic Interaction among Governments: An Overview of Empirical Studies,” International Regional Science Review, 26, 175-188.

Buss, Terry F. (2001) "The Effect of State Tax Incentives on Economic Growth and Firm Location Decisions: An Overview of the Literature,” Economic Development Quarterly, 15, 90-105.

Carree, Martin A. (2002) "Does Unemployment Affect the Number of Establishments? A Regional Analysis for US States,” Regional Studies, 36, 389-398.

Cheng, Shaoming and Huaqun Li. (2012) "New Firm Formation Facing Cultural and Racial Diversity,” Papers in Regional Science, 91, 759-774.

Dahl, Michael S. and Olav Sorenson. (2012) "Home Sweet Home: Entrepreneurs' Location Choices and The Performance of Their Ventures,” Management Science, 58, 1059-1071.

Delgado, Mercedes, Michael E. Porter, and Scott Stern. (2010) “Clusters and Entrepreneurship,” Journal of Economic Geography, 10, 495-518.

Elhorst, Paul J. (2010) “Applied Spatial Econometrics: Raising the Bar,” Spatial Economic Analysis, 5, 9-28.

Elhorst, Paul J. (2014) “Matlab Software for Spatial Panels,” International Regional Science Review, 37, 389-405.

Ellis, Stephen, and Cynthia Rogers. (2000) “Local Economic Development as a Prisoners' Dilemma: The Role of Business Climate,” Review of Regional Studies, 30, 315-330.

Evans, David S. and Boyan Jovanovic. (1989) "An Estimated Model of Entrepreneurial Choice under Liquidity Constraints,” Journal of Political Economy, 97, 808-827.

Evans, David S. and Linda S. Leighton. (1989) "Some Empirical Aspects of Entrepreneurship," American Economic Review, 79, 519-535.

Figueiredo, Octávio, Paulo Guimaraes, and Douglas Woodward. (2002) "Home-Field Advantage: Location Decisions Of Portuguese Entrepreneurs," Journal of Urban Economics, 52, 341-361.

Florida, Richard. (2002) The Rise Of The Creative Class. Basic Books: New York.

Florida, Richard. (2004). Cities And The Creative Class. Routledge: New York.

Florida Legislature's Office of Economic and Demographic Research (EDR). (2014) 2014 Local Government Financial Information Handbook, Available online in November 2017 at http://edr.state.fl.us/Content/local-government/reports/lgfih14.pdf.

Gartner, William B. (1989) “'Who Is an Entrepreneur?' Is the Wrong Question,” Entrepreneurship Theory and Practice, 13, 47-68.

Glaeser, Edward L., José A. Scheinkman, and Andrei Shleifer. (1995) "Economic Growth in a Cross-Section of Cities,” Journal of Monetary Economics, 36, 117-143.

Gottlieb, Paul D. (1995) “Residential Amenities, Firm Location, And Economic Development,” Urban Studies, 32, 1413-1436.

Greenhut, Melvin L. (1967). Plant Location in Theory and in Practice. University of North Carolina Press: Chapel Hill, North Carolina.

c Southern Regional Science Association 2018. 
Hébert, Robert F. and Albert N. Link. (1983) “The Entrepreneur: Mainstream Views and Radical Critiques,” Southern Economic Journal, 50, 611-612.

Hebert, Robert. F. and Albert N. Link. (1989) "In Search of the Meaning of Entrepreneurship," Small Business Economics, 1, 39-49.

Hoover, Edger M. (1948). Location of Economic Activity. McGraw-Hill: New York.

Isard, Walter. (1956) Location and Space-Economy: A General Theory Relating to Industrial Location, Market Areas, Land Use, Trade, and Urban Structure. MIT Press: Cambridge, Massachusetts.

Johnson, Peter S. and D. G. Cathcart. (1979) “The Founders of New Manufacturing Firms: A Note on the Size of Incubator Plants,” Journal of Industrial Economics, 28, 219-224.

Kelley, Donna J., Abdul Ali, Candida Brush, Andrew C. Corbett., Mahdi Majbouri, and Edward G. Rogoff. (2012) "Global Entrepreneurship Report: National Entrepreneurial Assessment for the United States of America," Available online in April 2016 at http://www.babson.edu/Academics/centers/blank-center/global-research/gem/Documents/ GEM\%20US\%202012\%20Report\%20FINAL.pdf.

Kerr, William R. and Ramana Nanda. (2009) “Democratizing Entry: Banking Deregulations, Financing Constraints, and Entrepreneurship,” Journal of Financial Economics, 94, 124149.

Knight, Frank H. (1921) Risk, Uncertainty and Profit. Houghton Mifflin: New York.

Koster, Sierdjan and Viktor A. Venhorst. (2014) “Moving Shop: Residential and Business Relocation by the Highly Educated Self-Employed,” Spatial Economic Analysis, 9, 436464.

LeSage, James P. (2014) "Spatial Econometric Panel Data Model Specification: A Bayesian Approach,” Spatial Statistics, 9, 122-145.

LeSage, James P. (2015) "Software for Bayesian Cross Section and Panel Spatial Model Comparison,” Journal of Geographical Systems, 17, 297-310.

LeSage, James P. and Kelly R. Pace. (2009) Introduction to Spatial Econometrics. Chapman and Hall: Boca Raton, Florida.

Lee, Sam Youl, Richard Florida, and Zoltan Acs. (2004) “Creativity and Entrepreneurship: A Regional Analysis of New Firm Formation,” Regional Studies, 38, 879-891.

Lumpkin, G. Tom and Gregory G. Dess. (1996) “Clarifying the Entrepreneurial Orientation Construct and Linking It to Performance,” Academy of Management Review, 21, 135172.

Mokry, Benjamin W. (1988) Entrepreneurship and Public Policy: Can Government Stimulate Business Startups?. Quorum Books: New York.

National Conference of State Legislatures. (2012) Promoting Entrepreneurship: Innovations in State Policy, Available online in October 2016 at http://www.ncsl.org/documents/fiscal/entrepreneurshipFINAL05.pdf.

OECD. (1998) Fostering Entrepreneurship: The OECD Jobs Strategy. OECD: Paris, France. 
Patrick, Carlianne. (2014) “The Economic Development Incentives Game: An Imperfect Information, Heterogeneous Communities Approach,” Annals of Regional Science, 53, 137-156.

Patrick, Carlianne. (2016) "Identifying the Local Economic Development Effects of Million Dollar Facilities,” Economic Inquiry, 54, 1737-1762.

Reynolds, Paul D., Brenda Miller, and Wilbur R. Maki. (1995) "Explaining Regional Variation in Business Births and Deaths: US 1976-88,” Small Business Economics, 7, 389-407.

Richardson, Harry W. (1969) Regional Economics: Location, Theory, Urban Structure, and Regional Change. Praeger Publishers: New York.

Shane, Scott. (2009) "Why Encouraging More People to Become Entrepreneurs Is Bad Public Policy,” Small Business Economics, 33, 141-149.

Shaver, Kelly G. and Linda R. Scott. (1991) "Person, Process, Choice: The Psychology of New Venture Creation,” Entrepreneurship: Theory and Practice, 16, 23-45.

Stam, Erik. (2007) "Why Butterflies Don't Leave: Locational Behaviour of Entrepreneurial Firms,” Economic Geography, 83, 27-50.

Tiebout, Charles M. (1956) “A Pure Theory of Local Expenditures,” Journal of Political Economy, 64, 416-424.

Tiebout, Charles M. (1957) "Location Theory, Empirical Evidence and Economic Evolution,” Papers and Proceedings of the Regional Science Association, 3, 74-86.

Tullock, Gordon. (1971) "Public Expenditures as Public Goods,” Journal of Political Economy, 79, 913-918.

Wennekers, Sander and Roy Thurik (1999) "Linking Entrepreneurship and Economic Growth,” Small Business Economics, 13, 27-55.

Wiklund, Johan and Dean Shepherd. (2003) "Aspiring for, and Achieving Growth: The Moderating Role of Resources and Opportunities,” Journal of Management Studies, 40, 1919-1941. 